DOI https://doi.org/10.30525/978-9934-588-92-1-90

\title{
ПЕРСПЕКТИВИ ПРОВАДЖЕННЯ В СУДІ ПРИСЯЖНИХ У КРИМІНАЛЬНИХ ПРОВАДЖЕННЯХ ЩОДО ЗЛОЧИНІВ ПРОТИ СТАТЕВОЇ СВОБОДИ ТА СТАТЕВОЇ НЕДОТОРКАНОСТІ
}

\author{
Мельничук T. I. \\ аспірант кафедри тактико-спечіальної підготовки \\ Академії Державної пенітенціарної служби \\ м. Чернігів, Украӥна
}

До законодавчих актів нашої держави нерідко вносяться зміни, не виключенням $\epsilon$ й кримінальний та кримінальний процесуальний закони.

Відповідно до змін, внесених згідно із Законом № 409-IX від 19.12.2019 санкція ч. 6 ст. 152 , ч. 6 ст. 153 Кримінального кодексу України (далі КК України) передбачає довічне позбавлення волі [8]. Таким чином, до кола кримінальних правопорушень, кримінальні провадження за вчинення яких підлягають розгляду судом присяжних, додаються злочини проти статевої свободи та недоторканості, вчинені відносно осіб, які не досягли чотирнадцяти років.

Враховуючи специфіку об'єкту злочинного посягання та додатковий об'єкт злочину, а саме: нормальний фізичний та психічний розвиток неповнолітнього або малолітнього, за умови наявності потерпілого відповідного віку [7], наслідки, заподіяні злочинами, передбаченими розділом 4 особливої частини КК України, є одними 3 найбільш тяжких. Дана обставина тісно пов'язана 3 однією із специфічних сторін процедури судового розгляду кримінальних проваджень, предметом яких $\epsilon$ вищезазначене кримінальне правопорушення. Відповідно до п. 2 ч. 2 ст. 27 КПК України суд може прийняти рішення про здійснення кримінального провадження у закритому судовому засіданні [5]. Вказівка даної норми направлена на обмеження кількості присутніх в судовому засіданні осіб, є важливим аспектом, оскільки у випадку, якщо даний факт стане надбанням громадськості, психологічний стан потерпілої від злочину особи може значно погіршитися, що, в свою чергу, призведе до збільшення періоду посттравматичного синдрому та спроможності продовжувати нормальне функціонування в соціумі. Не зважаючи на можливість проведення судового розгляду в закритому режимі, право 
обвинуваченого на розгляд справи судом присяжних збільшує кількість учасників процесу, які будуть утаємничені в детальні обставини справи, в той час як за порушення обов'язку, покладеного на присяжного п. 6 ч. 2 ст. 386 КПК України щодо нерозголошення відомостей, які стали йому відомі під час виконання ним обов'язків присяжного [5], не передбачено відповідальності. П. е) ч. 1 ст. 31 «Конвенції Ради Свропи про захист дітей від сексуальної експлуатації та сексуального насильства» наголошує на необхідності вживання законодавчих та інших необхідних заходів для захисту прав та інтересів жертв, відповідно до національного законодавства [3]. Виходить, що права потерпілої особи не є дієво захищеними в повній мірі. Також, слід звернути увагу на те, що право обвинуваченого на розгляд справи судом присяжних $є$ беззаперечним правом, що не потребує обговорення під час судового провадження, однак, з огляду на специфіку злочину та відповідний вік потерпілої особи, можливо, має сенс в даному випадку заслухати та врахувати позицію потерпілої сторони.

3 іншого боку, детальне обговорення та дослідження обставин вчиненого протиправного діяння даної категорії справ несе, в першу чергу, психологічне навантаження на суддів-непрофесіоналів, які $\epsilon$ психологічно непідготовленими, може призвести до необ'єктивного сприйняття обставин справи та формування внутрішнього переконання на основі аморальності та цинічності діяння загалом, в сукупності з тим чи іншим характером поведінки обвинуваченого та з урахуванням віку потерпілої особи, а не в рамках даної конкретної справи з наявною доказовою базою. В решті-решт, детальний опис події, яскраво виражені душевні переживання потерпілої сторони можуть унеможливити присутність присяжного під час здійснення судового провадження в залі судового засідання, в залежності від ступеня тонкості душевної організації останнього. З. Ф. Дільна, з думкою якої можна погодитися, зазначає, що неабияке значення для ефективного здійснення правосуддя судом присяжних має, в тому числі, підхід до їх відбору, за яким до даної процедури слід залучати фахівцівконсультантів, які в обов'язковому порядку повинні мати освіту психолога [2, с. 219].

Що ж стосується безпосередньо процедури дослідження доказів та ухвалення вироку в даній категорії справ судом присяжних, доцільно детальніше звернути увагу на наступне.

Так, окремої уваги заслуговує така стадія судового процесу як допит малолітнього потерпілого. Відповідно до ч. ч. 1, 2 ст. 23 КПК України суд досліджує докази безпосередньо, показання отримує усно. Відомості, які не були предметом безпосереднього дослідження, не 
можуть бути визнані доказами [5]. І.В. Басиста та В.О. Пришляк описують допит як багатопланову, складну слідчу дію, яка охоплює, в тому числі, процесуальний, організаційний та психологічний аспекти. Звертають увагу на важливість формулювання запитань таким чином, щоб не загострювати увагу на обставинах скоєного злочину, та на необхідності побудови правильної форми допиту [1, с. 2].

Відповідно до ч. 5 ст. 354 КПК України допит малолітнього потерпілого проводиться, зокрема, в присутності законного представника, педагога чи психолога. Відповідно до п. п. 1, 3 ч. 1 ст. 386 КПК України присяжний має право з дозволу головуючого ставити запитання учасникам процесу, які допитуються [5]. Варто зазначити, що вказівка на отримання дозволу головуючого більше стосується організації ведення судового процесу та спрямована на дотримання порядку в судовому засіданні, однак, жодним чином не стосується змісту та формулювання запитання, яке може бути поставлено некоректно або в неправильній формі. Чинним кримінальним процесуальним законодавством не передбачено право головуючого зняти поставлене присяжним запитання, оскільки останній входить до складу суду. Незважаючи на право протесту, яким наділені учасники, питання вже буде поставлене та почуте малолітньою особою. Доцільнішим було б запозичити досвід країн 3 класичною правовою моделлю суду присяжних, яка передбачає постановку питань присяжними через головуючого. Тож, головуючий в разі некоректного формулювання зміг би скорегувати питання та поставити його в належній формі.

Також, зазвичай експертному дослідженню піддаються матеріальнофіксовані сліди події, які залишаються на тілі, одязі потерпілої особи та підозрюваного, також на місці події, однак, на поведінку потерпілої особи впливають такі чинники, як сором, страх, та враховуючи вік, можливо, неповне усвідомлення вчиненого відносно неї діяння. Тому нерідкістю $є$ випадки, коли 3 моменту події до моменту фактичного повідомлення про злочин може спливти деякий час, що унеможливить надання експерту необхідної слідової інформації. Шляхом експертного дослідження можливо встановити лише факт вчинення діяння, а не причетність конкретної особи. Тож суду присяжних доведеться прийняти рішення, спираючись на непрямі докази. О.О. Хмиров зазначав, що при оцінці непрямих доказів найбільшу складність являє собою вирішення питання щодо достатності проміжних фактів для достовірних висновків стосовно істотних обставин справи [10]. Отже, можна стверджувати, що вагому роль при наданні оцінки вищезгаданого виду доказів відіграє внутрішнє переконання, за яким судді та присяжних відповідно до положень ст. 94 КПК України 362 
повинні оцінити кожен доказ [5]. В такому випадку сприйняття та аналіз професійними суддями та суддями-непрофесіоналами отриманої інформації може суттєво відрізнятися, що, в свою чергу, може призвести до розходження думки суддів та присяжних під час наради при ухваленні вироку. Відповідно до ч. ч. 2, 5 ст. 391 КПК України під час наради суду присяжних усі питання вирішуються простою більшістю голосів, а у випадку, коли серед більшості складу суду, відсутні судді, головуючий зобов'язаний надати допомогу присяжним у складенні судового рішення [5]. Дана норма $є$ досить неоднозначною та викликає питання щодо ії реалізації. Відсутня конкретизація механізму та меж такої «допомоги». Також викликає сумнів спроможність пересічних громадян, навіть не зважаючи на консультацію професійного судді, надати оцінку доказам, керуючись законом та мотивувати і обгрунтувати своє рішення, як того вимагають положення ст. ст. 94, 370 КПК України [5]. Також, слід врахувати, що в разі апеляційного оскарження колегія суддів апеляційної інстанції вирішує питання щодо законності та обгрунтованості вироку суду першої інстанції, керуючись загальними вимогами до застосування закону, не дивлячись на те, що вирок було написано присяжними, а не професійним суддею.

Отож, можна зазначити, що для ефективного здійснення правосуддя необхідно переглянути процедуру відбору присяжних, акцентувавши увагу на психологічних властивостях, притаманних кандидатам у присяжні.

\section{Література:}

1. Басиста І.В., Пришляк В.О. Особливості допиту неповнолітніх потерпілих від злочинів проти статевої свободи та статевої недоторканості. Науковий вісник Львівського державного університету внутрішніх справ. Серія юридична. Львів, 2008. № 2. С. 2.

2. Дільна З.Ф. Психологія присяжного при прийнятті ним судового рішення. Науковий вісник Львівського державного університету внутрішніх справ. Серія юридична. Львів, 2018. № 3. С. 219.

3. Конвенція Ради Європи про захист дітей від сексуальної експлуатації та сексуального насильства. URL: https://zakon.rada.gov.ua/ laws/show/994_927\#Text (дата звернення: 05.09.2020).

4. Кримінальний процесуальний кодекс України: офіц. текст. Київ : K, $2020.420 \mathrm{c}$.

5. Науково-практичний коментар до ст. 153 Кримінального кодексу України. URL: https://ips.ligazakon.net/document/KK004655 (дата звернення: 02.09.2020). 
6. Про внесення змін до деяких законодавчих акті України щодо впровадження Єдиного реєстру осіб, засуджених за злочини проти статевої свободи та статевої недоторканості малолітньої особи, та посилення відповідальності за злочини, вчинені проти статевої свободи та статевої недоторканості малолітньої особи: Закон України від 19.12.2019 p. № 409-IX. URL: https://zakon.rada.gov.ua/laws/show/ 409-20\#Техt (дата звернення: 02.09.2020).

7. Хмыров А.А. Косвенные доказательства. Москва: Юридическая литература, 1979. 184 с.

DOI https://doi.org/10.30525/978-9934-588-92-1-91

\title{
ЩОДО ПРОБЛЕМНИХ ПИТАНЬ ВИЗНАЧЕННЯ ПРАВОВОЇ КВАЛІФІКАЦІЇ ВЧИНЕНОГО КРИМІНАЛЬНОГО ПРАВОПОРУШЕННЯ ТА УЗГОДЖЕНОГО ПОКАРАННЯ ПРИ УКЛАДАННІ ТА ЗАТВЕРДЖЕННІ УГОД
}

\author{
Сіроткіна М. В. \\ кандидат юридичних наук, \\ здобувач кафедри кримінального процесу та криміналістики \\ Інституту права \\ Київського начіонального університету імені Тараса Шевченка \\ м. Київ, Украӥна
}

При укладанні угод про примирення та визнання винуватості суб'єкти їх укладення визначають правову кваліфікацію вчиненого кримінального правопорушення, за яке підозрюваний чи обвинувачений буде нести відповідальність (ст.ст. 471, 472 КПК України). У цьому аспекті необхідно вказати на відповідальність, яку покладено на суд кримінальним процесуальним законом, оскільки саме обов'язком суду $\epsilon$ встановлення відповідності правової кваліфікації правопорушення викладеним в угоді фактичним обставинам вчинення кримінального правопорушення.

Існує загроза того, що прокурор або потерпілий, з одного боку, та підозрюваний/обвинувачений - 3 іншого, досягнувши угоди про визнання винуватості або примирення, не позбавлені можливості викласти в тексті угоди обставини кримінального правопорушення, зазначивши при цьому зовсім іншу правову кваліфікацію вчиненого 